\title{
Catherine Magnien, Un exemplaire de la Deffence et illustration de la langue françoise de 1552
}

\section{Filippo Fonio}

\section{(2) OpenEdition}

1 Journals

\section{Edizione digitale}

URL: http://journals.openedition.org/studifrancesi/32976

DOI: 10.4000/studifrancesi.32976

ISSN: 2421-5856

\section{Editore}

Rosenberg \& Sellier

\section{Edizione cartacea}

Data di pubblicazione: 1 décembre 2005

Paginazione: 626

ISSN: 0039-2944

\section{Notizia bibliografica digitale}

Filippo Fonio, «Catherine Magnien, Un exemplaire de la Deffence et illustration de la langue françoise de 1552», Studi Francesi [Online], 147 (XLX | III) | 2005, online dal 30 novembre 2015, consultato il 19 avril 2021. URL: http://journals.openedition.org/studifrancesi/32976 ; DOI: https://doi.org/10.4000/ studifrancesi.32976

Questo documento è stato generato automaticamente il 19 avril 2021.

\section{(c) (1)}

Studi Francesi è distribuita con Licenza Creative Commons Attribuzione - Non commerciale - Non opere derivate 4.0 Internazionale. 


\title{
Catherine Magnien, Un exemplaire de la Deffence et illustration de la langue françoise de 1552
}

\author{
Filippo Fonio
}

\section{NOTIZIA}

CATHERINE MAGNIEN, Un exemplaire de la Deffence et illustration de la langue françoise de 1552, «Bibliothèque d'Humanisme et Renaissance», LXVI, 3 (2004), pp. 603-606.

1 Il presente contributo aggiunge un tassello alla storia delle edizioni delle opere di Joachim Du Bellay vivente l'autore. La studiosa rende infatti noto che l'edizione 1553 della Deffence presso Arnoul L'Angelier è preceduta da una datata al 1552, della quale enumera le principali differenze rispetto alla princeps del 1549 e alle altre edizioni ante 1560. Henri Chamard, curatore dell'edizione critica della Deffence nel 1948, tuttora insuperata e che tiene conto delle varianti del 1553, non era a conoscenza della stampa del 1552. 